\title{
Ultrasound evaluation of the temporomandibular joint in healthy children and adolescents
}

\section{Sağlıklı Çocuklarda Temporomandibular Eklemin Ultrason ile Değerlendirilmesi}

\author{
Hatice Arioz Habibi1*, Zuhal Bayramoglu², Emine Caliskan³, Mehmet Ozturk ${ }^{4}$ \\ 1.Department of Radiology, Private Varisson Radiology Center, Antalya, Turkey \\ 2.Department of Radiology, İstanbul University, Istanbul School of Medicine, İstanbul, Turkey \\ 3.Department of Radiology, Ministry of Health, University of Health Sciences, Kartal Lutfi Kirdar Education and Research Hospital, Istanbul, Turkey \\ 4.Department of Pediatric Radiology, Selçuk University Faculty of Medicine, Konya, Turkey
}

\section{ABSTRACT}

Objectives: The purpose of this study was to investigate normative values of the distance between the most lateral point of the articular capsule and the most lateral point of the mandibular condyle (LCCD), in children and adolescents. Since the disc is not always visible on ultrasound, LCCD measurement is a very practical indirect indicator for evaluating TMJ.

Methods: This prospective study evaluated 141 temporomandibular joints distance of 141 pediatric individuals with a median age of 9 years (5-13) for boys and 11 years (6.5-14) for girls, comprising 69 boys and 72 girls. LCCD measurements were made with the participants in the closed mouth position, and the relationship of these values with weight, height, age, gender and body mass index (BMI) was evaluated.

Results: Median LCCD values in age groups 2 and 3 were significantly higher than the age group $1(\mathrm{p}=0.001)$. There was no significant difference between median LCCD values in age group 2 and age group $3(p=0.5)$. No significant difference was found among the median LCCD values of the males $1.5 \mathrm{~mm}(1.2-1.8)$ and females $1.4 \mathrm{~mm}(1.1-1.6)$.

Conclusion: LCDD values increased with age, but no significant difference shown among the genders. However, a negative relation was detected with BMI. This study provides the normative quantitative values of TMJ distance which could be a reference point for upcoming studies. US is a diagnostic method that can be used in the follow-up and screening of children with TMD risk and general population. Since it does not include radiation, it can be safely repeated.

Keywords: Children, temporomandibular joint, Ultrasonography.

\section{ÖZ}

Amaç: Bu çalışmanın amacı, çocuklarda ve ergenlerde eklem kapsülünün lateral noktası ile mandibular kondilin en lateral noktası (LCCD) arasındaki mesafenin referans değerlerini belirlemektir. Disk ultrasonda her zaman görünmediğinden, LCCD ölçümü temporomandibular eklemi(TME) değerlendirmek için dolaylı bi gösterge olmakla beraber çok pratiktir.

Yöntemler: Prospektif çalışmamızda, medyan yașı erkeklerde 9 (5-13) ve kızlarda 11 (6.5-14) olan, 69 erkek ve 72 kız olgunun toplamda 141 TME mesafesi değerlendirildi. Katılımcılar yaş gruplarına göre 3'e ayrıldı. Ultrasonda yapılan LCCD ölçümlerinin cinsiyet, yaş, boy, kilo, vücut kitle indeksi (VKI) ile korelasyonı değerlendirildi.

Bulgular: Grup 2 ve 3'ün LCCD değeri grup 1'den anlamlı derecede yüksekti ( $p=$ $0,001)$. Ancak Grup 2 ve 3 arasında anlamlı fark yoktu $(p=0,5)$. LCCD değerleri erkeklerde $1,5 \mathrm{~mm}(1,2-1,8)$ ve kızlarda $1,4 \mathrm{~mm}(1,1-1,6)$ olarak bulundu.

Sonuç: Çalışmamızda LCDD değerleri yaşla birlikte artı̧ göstermekle beraber cinsiyetler arası anlamlı fark saptanmadı. LCCD ile VKI arasında negatif bir ilişki tespit edildi. Bu çalışma, gelecekteki çalışmalar için referans olabilecek TME mesafesinin normatif değerlerini sağlamaktadır. Ultrason, temporomandibular hastalık riski olan çocukların ve genel popülasyonun tarama ve takibinde kullanılabilecek bir tanı yöntemidir. Radyasyon içermediği için güvenle tekrarlanabilir.

Anahtar Kelimeler: Çocuk, Temporomandibular Eklem, Ultrasonografi

Received:11.03.2021 Accepted: 30.03.2021 Published (Online): 30.08.2021

*Corresponding Author: Hatice Arı̈̈z Habibi. Private Varisson Radiology Center, Yeşilbahçe Mah. Metin Kasapoğlu Cad. Nuri Mancar Apt No:42/A, 07160 Muratpaşa/ Antalya,+905057521798, arioz.hatice@gmail.com

ORCID: 0000-0002-4113-596X

To cited: Arioz Habibi H, Bayramoglu Z, Caliskan E, Ozturk M. Ultrasound Evaluation of The Temporomandibular Joint in Healthy Children and Adolescents. Acta Med. Alanya 2021;5(2):175-180 doi:10.30565/medalanya.895129 


\section{INTRODUCTION}

Tis he temporomandibular joint (TMJ) is one of the most commonly used joints in the human body and the only movable joint in the skull. Temporomandibular disorders (TMD) are characterized by pain and dysfunction involving the temporomandibular joint and masticator muscles. The incidence in children varies between $16-68 \%$ $[1,2]$. The TMJ disc has a biconcave shape with fibrocartilaginous structure like meniscus of the knee. The part of the disc that absorbs mechanical stress is the parts that adhere to the joint capsule [3]. One of the main causes of TMD is disc degeneration. Although many methods are used in TMJ imaging, no method has yet been agreed upon as a gold standard [4]. Magnetic resonance imaging (MRI) is the initial option for evaluation in TMJ dysfunction, thanks to its high soft tissue resolution. The main disadvantages of $\mathrm{MRI}$ are its non-availability in some centers, high cost and restricted use in patients with claustrophobia, a cardiac pacemaker or metallic prostheses [5]. Computed tomography (CT) can be used in assessment of underlying bone pathologies such as bone erosion, fractures and postoperative deformities [6]. Although the advantages of use are emphasized, it should not be forgotten that repetitive rounds increase radiation exposure when follow-ups are performed with $\mathrm{CT}$, and alternative techniques should be used in these instances [7].

Ultrasound (US) is a cost-effective, non-invasive and quick examination technique that is accessible and ensures dynamic evaluation without ionizing radiation. Thus, it is a very beneficial screening tool for the assessment of TMJ and masticatory muscles, in particular with the pediatric age group [8]. The use of US plays an important role in screening and follow-up, especially in screening children with JRA or children at risk of temporomandibular joint disease (TMD). Therefore, we believe that determination of TMJ ultrasound properties and reference values will be useful.

In this study, LCCD values of children and adolescents were analyzed. The differences of this value between pre-school age, school age and adolescent groups were determined. In addition, we assessed changes based on sex, height, weight and body mass index (BMI).

\section{MATERIALS AND METHODS}

Study subjects and design

In this study, we assessed 141 TMJ distances of 141 pediatric subjects with a median age of 9 years (5-13) for boys and 11 years (6.5-14) for girls, comprising 69 boys and 72 girls, from April to September 2020. Local ethics committee approval was obtained prior to initiation of the study and informed consent was obtained from the parents of the participants, just before the ultrasound examination. We included only healthy individuals: those without orofacial pain, TMJ pathology history or systemic disorders that might have an influence on the TMJ. Participants were first examined by the dentist and individuals with no dislocation findings upon physical examination and ultrasound, were included in the study. Some individuals were excluded, for the following reasons: refusal to participate, aged under 3 , presence of systemic inflammatory arthritis, facial trauma, mandibular growth disturbance rheumatological diseases or prior surgery.

Participants were divided into 3 groups: 3-6 years $(n=47$, preschool), 7-12 years $(n=47$, school) and 13-17 years ( $n=47$, adolescents). Sociodemographic information, including gender, weight, height and BMI was recorded. BMI was calculated as $B M I=$ weight $(\mathrm{kg}) /$ height $(\mathrm{m} 2)$. The complicated structure of TMJ is shown schematically in Fig 1 [5]. The TMJ capsule is a membrane that connects to the disc and neck of the mandibular condyle.

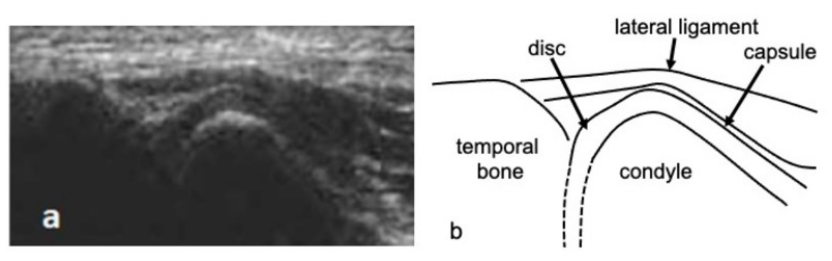

Fig 1. a) Parallel to Camper line US view of the TMJ. b) The broken lines match to the structures that are not able to be visualized. TMJ: temporomandibular joint

The fibrocartilage joint disc divides the joint space into two compartments; there are capsula articularis surrounding the TMJ and various supporting ligaments. The mandibular condyle, 
glenoid fossa and joint cartilage are covered with a fibrous tissue. Between the condyle and the glenoid fossa there is a fibrous cartilaginous tissue. The joint is surrounded as a whole by a synovial membrane, above which is the joint capsule. US examination was completed using an AplioTM 500 Platinum ultrasonography device (Canon Medical Systems, Japan) with a 5-14 MHz high frequency linear probe and using the 'small parts' preset. The children were assessed in motionless supine position. Right TMJ measurements were used and the disc images were obtained with heads turned to the left side and closed mouth position. TMJ disc images were taken parallel to the camper plane (Fig 2). Ultrasound measurements were performed by the same pediatric radiologist with 15 years of ultrasound experience, repeated 3 times and the mean value of measurements were recorded. In each scan, the operator measured the distance between the most lateral point of the articular capsule and the most lateral point of the mandibular condyle. Since the disc was not seen directly on all ultrasound images, the LCCD was used as an indirect marker to state the disc situation.

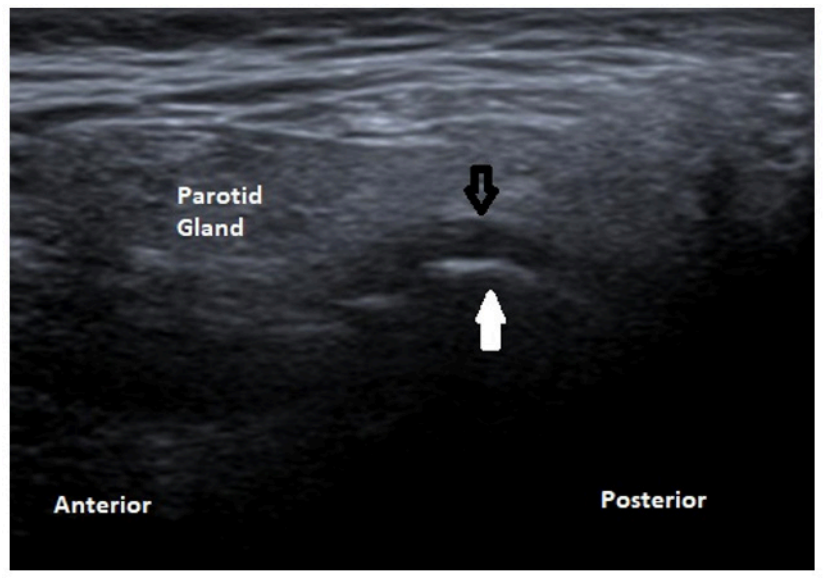

Fig 2. Extra-articular portion of the TMJ disc and articular capsule indicated between black and white arrow on the B-mode image. Hyperechoic line (Black arrow) running lateral and parallel to the lateral surface (White arrow) of the mandibular condyle, indicating the articular capsule. The distance between the articular capsule and the mandibular condyles' lateral surface showed between the apexes of the black and white arrow.

\section{Statistical Analysis}

All the data was processed in Microsoft Office Excel and transferred to the SPSS (version 21.0, IBM Corp.) software for statistical analysis. The distribution of the data was evaluated with the
Kolmogorov-Smirnov test, with close attention given to the skewness and kurtosis. Descriptive statistics of the data were demonstrated as median with interquartile range (IQR). Differences between median values of age, height, weight, BMI and LCCD parameters among the gender groups were compared using the Mann-Whitney $U$ test. Differences between median values of age, height, weight, BMI and LCCD parameters among the three age groups were compared using the Kruskal-Wallis test. A comparison among two age groups was evaluated using the Mann-Whitney $U$ t-test. Correlation analysis of the age, height, weight, BMI with LCCD parameters were tested with Spearman's correlation analysis. The scattered dot graphics were plotted for correlation of age and BMI parameters with LCCD values (Fig. 3a-b). Variables were studied at the 95\% confidence interval with $p<0.05$ accepted as statistically significant.
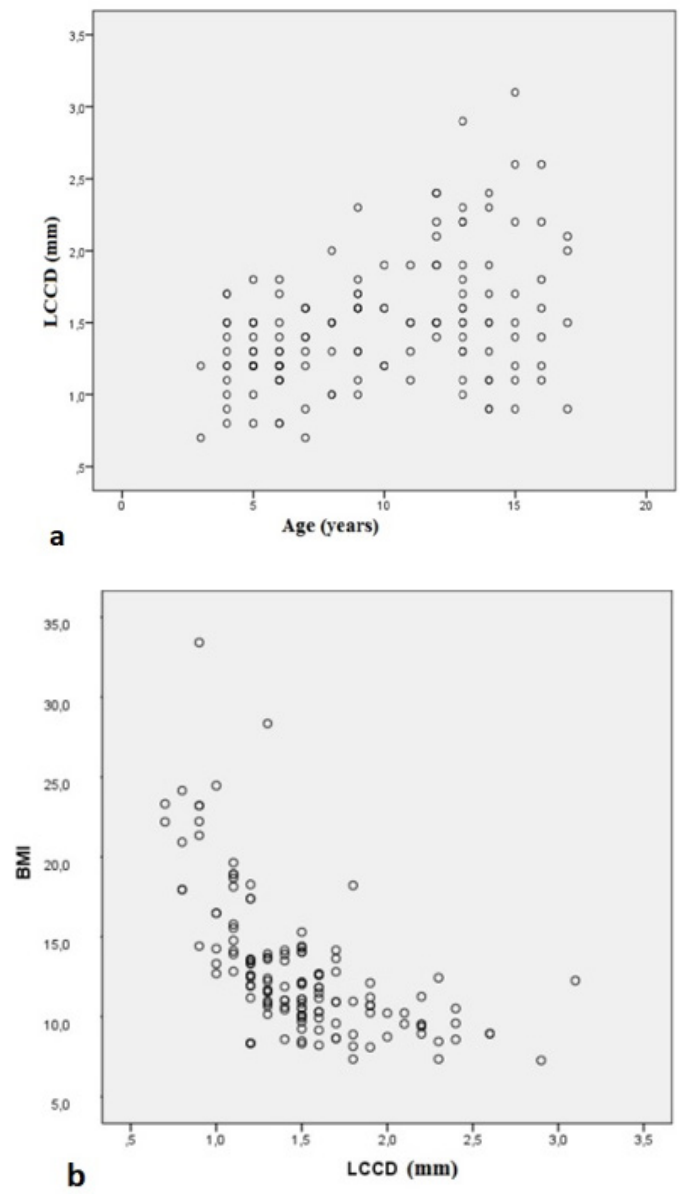

Fig $3 a-b)$ The scattered dot graphics were plotted for correlation of age and BMI parameters with LCCD values 


\section{RESULTS}

Descriptive statistics of the age, height, weight, BMI and LCCD in gender and age groups are offered in Tables 1 and 2. No significant difference was found among the median ages of the males (9 (5-13)) years) and females (11 (6.5-14)) years) $(p=0.06)$. No significant differences were found in median height, weight and BMI values of the males and females ( $p>0.05)$. No significant difference was found among the median LCCD values of the males $(1.5(1.2-1.8) \mathrm{mm})$ and females $(1.4(1.1-1.6)) \mathrm{mm})(p=0.11)$. There were statistically significant differences in median values of age, height and weight values, between each age group comparisons. Median BMI value in age group 3 was significantly higher than the median BMI values in age group 1 and age group 2 , $(p=0.049$ and $p=0.003$, respectively $)$. There was no significant difference between median BMI values in age group 1 and age group $2(p=0.3)$. Median LCCD values in age groups 2 and 3 were significantly higher than the median LCCD value in age group $1(p=0.001)$. There was no significant difference between median LCCD values in age group 2 and age group $3(p=0.5)$.

Table 1. Descriptive statistics of age, height, weight, body mass index and LCCD parameters by gender groups

\begin{tabular}{|c|c|c|c|c|}
\hline \multirow[t]{3}{*}{ Parameter } & \multicolumn{3}{|c|}{ Descriptive statistics } & \multirow[t]{3}{*}{$\mathrm{p}$} \\
\hline & \multicolumn{3}{|c|}{ Median (Interquartile Range) } & \\
\hline & Girls (n:69) & Boys (n:72) & All(n:141) & \\
\hline Age (years) & $11(6.5-14)$ & $9(5-13)$ & $9(6-13)$ & 0.06 \\
\hline Height $(\mathrm{cm})$ & $\begin{array}{l}141(119- \\
156)\end{array}$ & $\begin{array}{l}128.5(116- \\
153)\end{array}$ & $\begin{array}{l}135(118- \\
155)\end{array}$ & 0.27 \\
\hline Weight (kg) & $35(22-50)$ & $27(20-47)$ & $30(21-48)$ & 0.4 \\
\hline BMI $(\mathrm{kg} / \mathrm{m} 2)$ & $\begin{array}{l}12.26 \\
(10.36-14.20)\end{array}$ & $\begin{array}{l}11.17(9.55- \\
13.58)\end{array}$ & $\begin{array}{l}11.88 \\
(10.1- \\
14.09)\end{array}$ & 0.085 \\
\hline $\operatorname{LCCD}(\mathrm{mm})$ & $1.4(1.1-1.6)$ & $1.5(1.2-1.8)$ & $\begin{array}{l}1.5(1.2- \\
1.7)\end{array}$ & 0.11 \\
\hline
\end{tabular}

p values by the Mann-Whitney U test.

Correlation analysis of age, height, weight and BMI values with LCCD parameters are found in Table 3. There was highly significant mild to moderate positive correlations of age $(r=0.35)$, height $(r=0.38)$ and weight $(r=0.40)$ with LCCD values $(p=0.001)$. There was highly significant moderate negative correlation of BMI $(r=-0.68)$ with LCCD values $(p=0.001)$.
Table 2. Descriptive statistics age, height, weight, body mass index and LCCD parameters by age groups

\begin{tabular}{|c|c|c|c|c|c|}
\hline & Group 1 & Group 2 & Group 3 & \multirow{2}{*}{\multicolumn{2}{|c|}{$p$}} \\
\hline & $\begin{array}{l}\text { 3-6 years } \\
\text { (n:47) } \\
\text { Median } \\
\text { (IQR) }\end{array}$ & $\begin{array}{l}\text { 7-12 years } \\
(\mathrm{n}: 47) \\
\text { Median } \\
(\mathrm{IQR})\end{array}$ & $\begin{array}{l}\text { 13-17 years } \\
(\mathrm{n}: 47) \\
\text { Median } \\
(\mathrm{IQR})\end{array}$ & & \\
\hline $\begin{array}{l}\text { Age } \\
\text { (years) }\end{array}$ & $5(4-6)$ & $9(8-11)$ & $14(13-15)$ & $0.001^{*}$ & \begin{tabular}{|l}
1 vs $2: 0.001^{\prime}$ \\
1 vs $3: 0.001^{\prime}$ \\
2 vs $3: 0.001^{\prime}$
\end{tabular} \\
\hline $\begin{array}{l}\text { Height } \\
(\mathrm{cm})\end{array}$ & $\begin{array}{l}114 \\
(108-119)\end{array}$ & $\begin{array}{l}135 \\
(127-150)\end{array}$ & $\begin{array}{l}160 \\
(152-163)\end{array}$ & $0.001^{*}$ & $\begin{array}{l}1 \text { vs } 2: 0.001^{\prime} \\
1 \text { vs } 3: 0.001^{\prime} \\
2 \text { vs } 3: 0.001^{\prime} \\
1 \text { vs } 2: 0.001^{\prime} \\
1 \text { vs } 3: 0.001^{\prime} \\
2 \text { vs } 3: 0.001^{\prime}\end{array}$ \\
\hline $\begin{array}{l}\text { Weight } \\
(\mathrm{kg})\end{array}$ & $19(17-23)$ & $30(24-40)$ & $53(47-61)$ & $0.001^{*}$ & \begin{tabular}{|l}
1 vs $2: 0.001^{\prime}$ \\
1 vs $3: 0.001^{\prime}$ \\
2 vs $3: 0.001^{\prime}$
\end{tabular} \\
\hline $\begin{array}{l}\text { BMI } \\
(\mathrm{kg} / \mathrm{m} 2)\end{array}$ & \begin{tabular}{|l|}
11.88 \\
$(10.08-$ \\
$13.59)$
\end{tabular} & $\begin{array}{l}11.09 \\
(9.91-12.4)\end{array}$ & \begin{tabular}{|l|}
13.5 \\
$(10.25-$ \\
$18.13)$ \\
\end{tabular} & $0.002^{*}$ & $\begin{array}{l}1 \text { vs } 2: 0.3 \\
1 \text { vs } 3: 0.049 \\
2 \text { vs } 3: 0.003\end{array}$ \\
\hline $\begin{array}{l}\text { LCCD } \\
(\mathrm{mm})\end{array}$ & $\begin{array}{l}1.2(1.1- \\
1.5)\end{array}$ & $\begin{array}{l}1.5(1.3- \\
1.7)\end{array}$ & $1.5(1.2-2.1)$ & $0.001^{*}$ & $\begin{array}{l}1 \text { vs } 2: 0.001^{\prime} \\
1 \text { vs } 3: 0.001^{\prime} \\
2 \text { vs } 3: 0.5^{\prime}\end{array}$ \\
\hline
\end{tabular}

P-values by the Kruskal Wallis* and Mann-Whitney U tests'

Bold p-values represent statistically significant results IQR: Interquartile range

Table 3. Correlation results of the auxological parameters with LCCD

\begin{tabular}{|c|c|c|c|}
\hline \multicolumn{2}{|l|}{ Parameters } & $\mathrm{p}$ & $\mathrm{R}$ \\
\hline \multirow{4}{*}{ LCCD } & Age & 0.001 & 0.35 \\
\hline & Height & 0.001 & 0.38 \\
\hline & Weight & 0.001 & 0.40 \\
\hline & BMI & 0.001 & -0.68 \\
\hline
\end{tabular}

P-values by Spearman's correlation analysis.

Bold p-values represent statistically significant results

\section{DISCUSSION}

TMD is usually caused by an anomalous relationship between the disc and neighboring articular structures. Although dislocation is most common towards the anterior, it can be in all directions [9]. TMJ problems containing the articular disc, capsule and muscles of mastication, occur with a variety of signs including pain, clicking and functional restriction [10]. Myofascial pain and regional tenderness are usual symptoms in TMJ diseases. But studies show that TMD may not cause any symptoms in childhood; in cases with symptoms, the diagnosis of head or ear pain is made by a pediatrician and otolaryngologist, and the actual diagnosis can be ignored [11]. 
There is a multifactorial etiology in the existence of TMD in children as well as in adults. Parafunctional habits such as trauma, malocclusion and bruxism, nail biting and finger sucking are among the main etiological causes of TMD in childhood [12, 13]. In order to prevent sustained orofacial diseases in adulthood, individuals who are at risk of TMD should undergo a routine examination of the TMJ. However, it is not practical to examine every child with an MRI or a CT scan. Long-term patient compliance is difficult to achieve and the need for sedation may cause problems in children while screening with MRI. CT is not appropriate as a screening method as a result of the ionizing radiation. Ultrasound can be used as a scanning method in children with head or ear pain, noise in the jaw and mandibular asymmetry, however use of this method can sometimes be difficult in the pediatric age group to achieve the examination. Therefore, it is important to determine a practical, easily measurable reproducible standard measurement parameter while evaluating TMD in ultrasound. In our study, by measuring the LCCD value in ultrasound, a fast and reliable preliminary evaluation is achieved in terms of TMD scanning.

We found the mean LCDD value in age group 1 (3-6 years old) to be $1.2(1.1-1.5) \mathrm{mm}$, in group 2 (7-12 years) $1.5(1.3-1.7) \mathrm{mm}$ and in group 3 (13-17 years) $1.5(1.2-2.1) \mathrm{mm}$. Median LCCD values in age groups 2 and 3 were significantly higher than the median LCCD value in age group 1. Although the LCDD value increased with age, there was no significant difference between the 7-12 and the 13-17 age groups. It has been suggested that indirect ultrasonographic signs can be used, due to the difficulty in observing the entire disc. For Hayashi et al., disc displacement should be suspected if the US reveals a distance between the articular capsule and the lateral surface of the mandibular condyle (LCCD) of 4 $\mathrm{mm}$ or more [14]. Our reference values can be used for quick control in ultrasound and in this study, no significant differences were determined in LCCD values between the sexes.

Otherwise, we found no relationship between height, weight and age with the LCCD values and these did not vary by gender. The effect of gender difference on TMD has been discussed extensively in the literature and while the signs and symptoms in childhood do not differ much by gender, it has been reported that symptoms are observed in young adult girls 1.5 to 2 times more compared to boys. This difference is possibly the result of pain sensitivity of girls and hormonal differences between the two genders [7, 15].

There was highly significant moderate negative correlation of BMI ( $r=-0.68)$ with LCCD values. An increase in LCCD value was accepted as significant as the secondary finding of internal derangement of the TMJ. However, its negative relationship with BMI may be secondary to a reduction in distance due to osteoarthritis. In a recent mouse model study, it was found that obesity could cause temporomandibular joint pathological changes and it was determined that both excessive compressive mechanical force and high fat diet induced obesity, caused TMJ osteoarthritis-like changes [16].

Destructive changes in the joint disc and synovial structures can be seen particularly in diseases that can show TMJ involvement, such as JIA, joint effusion, sclerosis, flattening of the joint condyle and inflammatory erosions. Pain is a rare symptom in children with TMJ involvement in JIA, therefore the focus should be on preventing mandibular growth disorders that may precede malocclusion and jaw dysfunction. US can also be used to monitor the progress of TMJ involvement and response to treatment [17].

In order to determine US reference values for TMJ and to create a guideline, multi-center studies with larger series in different age and disease groups are needed. The data of our study can be a source for these studies.

TMD usually develops due to rheumatological, degenerative changes and inflammatory processes. Familiarity with the evaluation of TMJ by US and knowing the value ranges of US parameters enables early identification of possible pathological differences. Coming studies should work on the connection among histopathological changes and US results in temporomandibular joint and TMD. Routine use of US will decrease the redundant procedures and rising the cost effectiveness.

The main limitation of our study is the limited number 
of cases. Additionally, measurements were made only by one operator, which hinders assessment of inter- and intraobserver reliability. We did not have all of the laboratory information necessary to verify that the individuals were completely healthy. Participants were first examined by the dentist. Patients with no dislocation findings on physical examination and ultrasound were included in the study. Asymptomatic cases with disc displacement may have affected our results. Only the right TMJ of each patient was appraised and no comparisons were made among the sides.

Conclusion: US is a noninvasive diagnostic tool that can be used to evaluate TMJ and TMD in the pediatric age group. LCDD values increased with age, but no significant difference was shown between genders. However, a negative relation was detected with BMI. This study provides the normative quantitative values of TMJ distance which could be a reference point for upcoming studies. US is a diagnostic method that can be used in the follow-up and screening of children with TMD risk and general population and since it does not include radiation, it can be safely repeated.

Conflict of Interest: The author has no conflict of interest related to this article.

Funding sources: The author declared that this study has received no financial support

Ethics Committee Approval: Selçuk Üniversity Local Etic Comittee 19.02.2020/ 2020-85

Peer-review: Externally and internally peer reviewed.

\section{REFERENCES}

1. Ribeiro RF, Tallents RH, Katzberg RW, Murphy WC, Moss ME, Magalhaes AC, et al. The prevalence of disc displacement in symptomatic and asymptomatic volunteers aged 6 to 25 years. J Orofacial Pain. 1997;11:37-47. PMID: 10332309

2. Klatkiewicz T, Gawriołek K, Pobudek Radzikowska M, Czajka-Jakubowska A. Ultrasonography in the diagnosis of temporomandibular disorders: a meta-analysis. Med Sci Monit. 2018;24:812-7. DOI: 10.12659/MSM.908810

3. Tomas X, Pomes J, Berenguer J, Quinto L, Nicolau C, Mercader JM, Castro V. MR imaging of temporomandibular joint dysfunction: a pictorial review. Radiographics. 2006;26(3):765-81. DOI: 10.1148/rg.263055091

4. Boeddinghaus R, Whyte A. Trends in maxillofacial imaging. Clin Radiol. 2018;73(1):418. DOI: 10.1016/j.crad.2017.02.015

5. Elias FM, Goldenberg Birman E, Matsuda CK, Souza Oliveira IR, Jorge WA. Ultrasonographic findings in normal temporomandibular joints. Braz Oral Res. 2006;20(1):25-32. DOI: 10.1590/s1806-83242006000100006

6. Tamimi D, Kocasarac HD, Mardini S. Imaging of the temporomandibular joint. Semin Roentgenol. 2019;54(3):282-301. DOI: 10.1053/j.ro.2019.03.007

7. Özden M, Savaş S. Clinical Findings and Treatment Manifestations of Temporomandibular Disorders in Children and Young Adults: Review of The Literature. Journal of Ege University School of Dentistry. 2016;37(2):66-74. DOI: 10.5505/eudfd.2016.30306.

8. Siva Kalyan U, MoturiK Rayalu P. The role of ultrasound in diagnosis of temporomandib- ular joint disc displacement: a case control study. J Maxillofac Oral Surg. 2018:17:3838. DOI: $10.1007 / \mathrm{s} 12663-017-1061-4$

9. Butts R, Dunning J, Perreault T, Mettille J, Escaloni J. Pathoanatomical characteristics of temporomandibular dysfunction: Where do we stand? (Narrative review part 1). J Bodyw Mov Ther. 2017;21(3):534-40. DOI: 10.1016/j.jbmt.2017.05.017

10. Takashima M, Arai Y, Kawamura A, Hayashi T, Takagi R. Quantitative evaluation of masseter muscle stiffness in patients with temporomandibular disorders using shear wave elastography. J Prosthodont Res. 2017;61(4):432-8. DOI: 10.1016/j.jpor.2017.01.003

11. Muhtarogullari M, Demirel F, Saygili G. Temporomandibular disorders in Turkish children with mixed and primary dentition: prevalence of signs and symptoms. Turk J Pediatr 2004;46(2):159-63. PMID: 15214746

12. Seraj B, Ahmadi R, Mirkarimi M, Ghadimi S, Beheshti M. Temporomandibular disorders and parafunctional habits in children and adolescence: a Review. Journal of Dentistry of Tehran University of Medical Sciences. 2009;6(1):37-45.

13. Küçükeşmen $\mathrm{C}$, Sönmez $\mathrm{H}$. Temporomandiular joint dysfunction syndrome in children and adolescences S.D.Ü. Tıp Fak. Derg. 2007;14(3):39-47.

14. Hayashi T, Ito J, Koyama J, Yamada K. The Accuracy of Sonography for Evaluation of Internal Derangement of the Temporomandibular Joint in Asymptomatic Elementary School Children: Comparison with MR and CT. AJNR Am J Neuroradiol. 2001;22(4):728-34. PMID: 11290488

15. Barbosa Tde S, Miyakoda LS, Pocztaruk Rde L, Rocha CP, Gavião MB. Temporomandibular disorders and bruxism in childhood and adolescence: review of the literature. Int J Pediatr Otorhinolaryngol. 2008;72(3):299-314. DOI: 10.1016/j.jporl.2007.11.006

16. Du J, Jiang Q, Mei L, Yang R, Wen J, Lin S, Li H. Effect of high fat diet and excessive compressive mechanical force on pathologic changes of temporomandibular joint. Sci Rep. 2020; 10(1):17457. DOI: 10.1038/s41598-020-74326-z

17. Assaf AT, Kahl-Nieke B, Feddersen J, Habermann CR. Is high-resolution ultrasonography suitable for the detection of temporomandibular joint involvement in children with juvenile idiopathic arthritis? Dentomaxillofac Radiol. 2013;42(3):20110379. DOl: 10.1259/dmfr.20110379

18. Larheim TA, Westesson P, Sano T. Temporomandibular joint disk displacement: comparison in asymptomatic volunteers and patients. Radiology. 2001;218:428-32. DOI: 10.1148/radiology.218.2.r01fe11428

\begin{tabular}{|l|l|}
\hline Author/ORCID & Authorship Contrubition \\
\hline $\begin{array}{l}\text { Hatice Arioz Habibi } \\
\text { 0000-0002-4113-596X }\end{array}$ & $\begin{array}{l}\text { Consept, design, materials, data collection; } \\
\text { Interpretation, literature search, manuscript } \\
\text { writing, final approval, critical review }\end{array}$ \\
\hline $\begin{array}{l}\text { Zuhal Bayramoglu } \\
0000-0002-2080-2647\end{array}$ & $\begin{array}{l}\text { Consept, design, manuscript writing, } \\
\text { Interpretation, final approval, critical review. }\end{array}$ \\
\hline $\begin{array}{l}\text { Emine Çalıskan } \\
0000-0001-9869-1396\end{array}$ & $\begin{array}{l}\text { Consept, design, materials, data collection; } \\
\text { Interpretation, final approval, critical review. }\end{array}$ \\
\hline $\begin{array}{l}\text { Mehmet Ozturk } \\
0000-0001-5585-1476\end{array}$ & $\begin{array}{l}\text { Consept, design, materials, data collection; } \\
\text { Interpretation, final approval, critical review. }\end{array}$ \\
\hline
\end{tabular}

